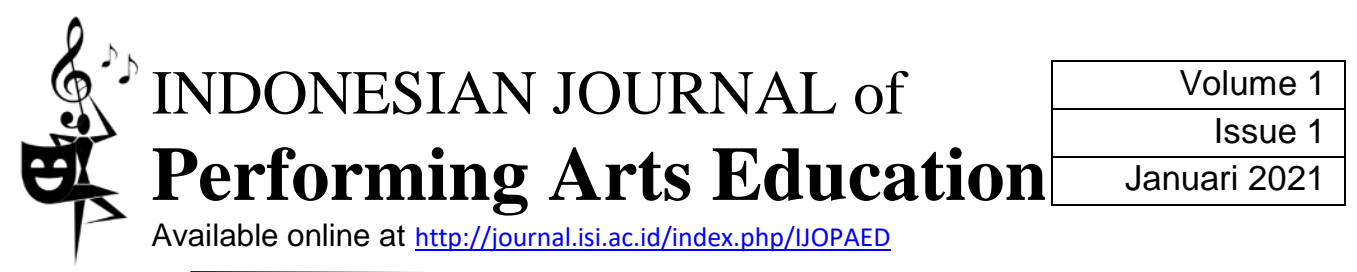

\title{
METODE PEMBELAJARAN TARI RUMEKSA DI SANGGAR DHARMO YUWONO PURWOKERTO
}

\author{
Galuh Destari Kumala Dewi ${ }^{1}$, Sarjiwo ${ }^{2}$, Antonia Indrawati ${ }^{3}$ \\ ${ }^{1}$ Institut Seni Indonesia Yogyakarta; galuhdesta77@gmail.com \\ ${ }^{2}$ Institut Seni Indonesia Yogyakarta; sarjiwo@isi.ac.id \\ ${ }^{3}$ Institut Seni Indonesia Yogyakarta; antonia.indrawati@isi.ac.id
}

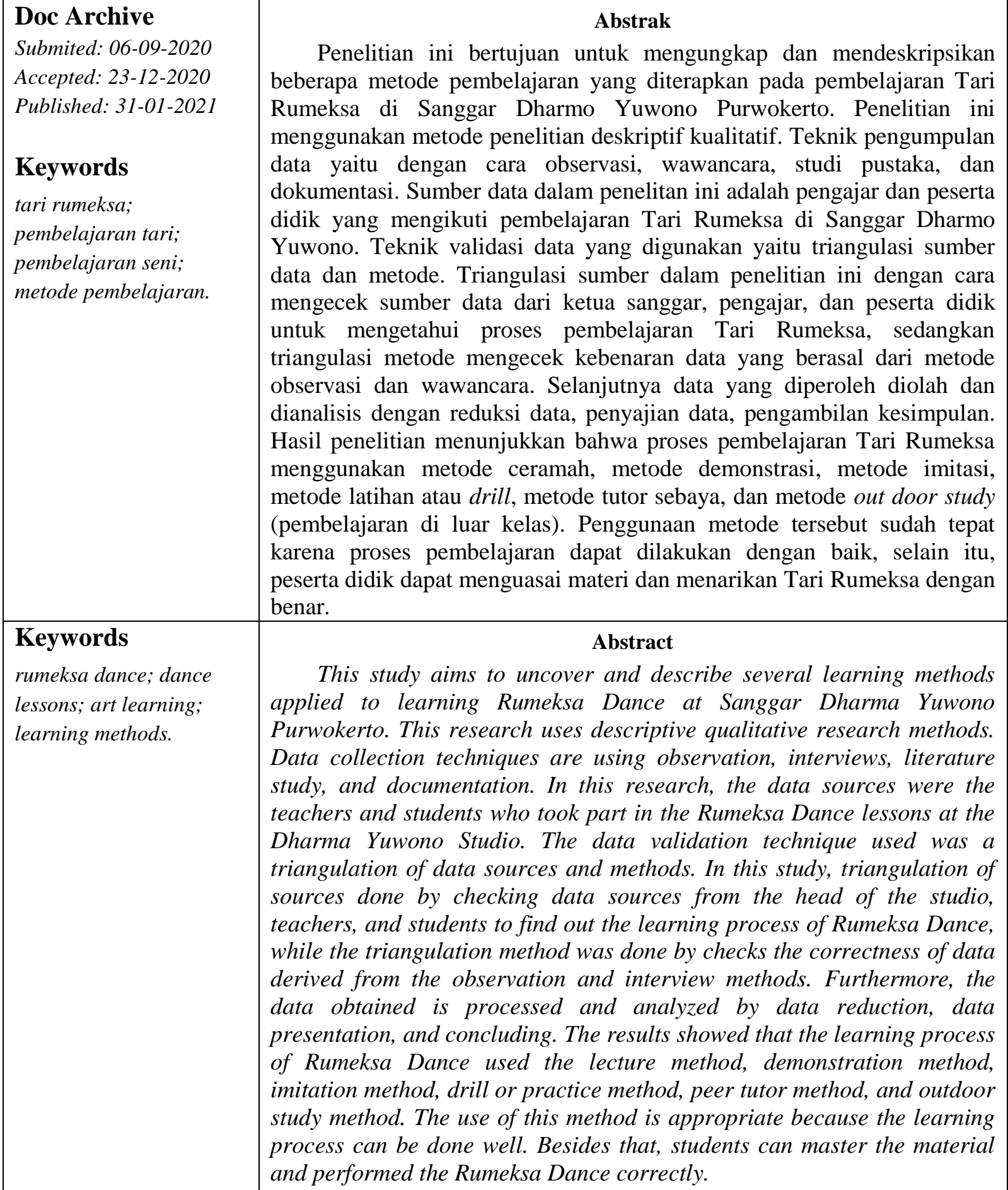




\section{Pendahuluan}

Di Kabupaten Banyumas terdapat delapan sanggar tari yang masih aktif, satu diantaranya adalah Sanggar Dharmo Yuwono. Sanggar Dharmo Yuwono terletak di Purwokerto Timur, Banyumas, Jawa Tengah. Sanggar Dharmo Yuwono berdiri pada tahun 1979 di bawah naungan Yayasan Sosial Panti Asuhan Yatim Piatu dan Anak Terlantar Dharmo Yuwono. Sanggar Dharmo Yuwono kini sudah diakui keberadaannya oleh Dinas Pemuda, Olahraga, Kebudayaan, dan Pariwisata (Dinporabudpar) Kabupaten Banyumas. Sanggar ini selalu aktif dalam mengikuti kegiatan yang berhubungan dengan agenda pariwisata maupun kebudayaan.

Pembelajaran yang berkualitas tercipta karena adanya metode yang digunakan oleh pengajar dalam suatu proses pembelajaran. Metode adalah suatu cara yang diperoleh untuk mencapai tujuan yang akan dicapai (El Khuluqo, 2017, p. 60). Penerapan metode pembelajaran berkaitan erat dengan pengembangan belajar mandiri, sebab metode yang tepat akan menumbuhkan motivasi belajar yang baik, serta mendorong belajar mandiri (Mudjiman, 2007, p. 81). Pemilihan berbagai metode yang tepat dapat menciptakan proses belajar mengajar yang menarik. Ketepatan penggunaan metode pembelajaran juga tergantung dengan tujuan, isi, dan proses pembelajaran. Maka dari itu, penyampaian materi di Sanggar Dharmo Yuwono selalu memperhatikan metode yang digunakan dalam setiap pembelajarannya.

Materi yang disampaikan pada pembelajaran disesuaikan dengan tingkatan masing-masing kelas, hal ini yang membuat Sanggar Dhamo Yuwono menjadi berbeda dari sanggar yang ada di Banyumas. Sanggar Dharmo Yuwono memiliki lima tingkatan kelas yaitu tingkat pertama, kedua, ketiga, keempat dan terampil dengan pengajar yang berbeda pada setiap tingkatannya. Pengajar di Sanggar Dharmo Yuwono menerapkan metode yang berbeda sesuai dengan situasi, jenis tarian yang diajarkan, dan kondisi anak yang diampu. Materi pembelajaran tari di Sanggar Dharmo Yuwono terbagi dalam dua kategori, yaitu tari klasik dan tari kreasi.

Salah satu tari kreasi yang diajarkan adalah Tari Rumeksa. Pembelajaran Tari Rumeksa ini diajarkan pada tingkatan keempat, karena pada tingkat keempat ini dianggap sudah mampu dan sudah melewati tingkatan dasar tari. Tari Rumeksa ini selalu dibawakan dalam mengikuti festival atau lomba tari tingkat kabupaten maupun provinsi hingga mendapat penghargaan, hal ini disebabkan karena Tari Rumeksa sudah menjadi ikon di Banyumas. Pembelajaran Tari Rumeksa yang diajarkan pada tingkatan keempat pastinya menggunakan metode tertentu sehingga membuat pembelajaran berhasil, dan menghasilkan peserta didik yang berkualitas.

Pada rangkaian sistem pembelajaran, metode pembelajaran dapat diartikan sebagai cara atau pola yang khas dalam memanfaatkan berbagai prinsip dasar pendidikan serta teknik dan sumber daya yang terkait lainnya, agar terjadi proses pembelajaran pada diri pembelajar (Ginting, 2008, p. 42). Metode Pembelajaran merupakan cara yang digunakan untuk mengimplementasikan rencana yang sudah disusun dalam bentuk kegiatan nyata dan praktis untuk mencapai tuuan pembelajaran (Kaniah, 2017, p. 15).

Suatu proses pembelajaran terdapat sejumlah metode pembelajaran yang dapat digunakan oleh pengajar, yaitu: (1) Metode ceramah, metode ini telah gunakan sebagai alat komunikasi lisan antara guru dan peserta didik dalam interaksi pembelajaran; (2) Metode Eksperimen, metode pemberian kesempatan kepada peserta didik perorangan atau kelompok untuk dilatih melakukan suatu proses atau percobaan; (3) Metode Demonstrasi, merupakan metode mengajar dengan cara memperagakan suatu benda tertentu yang tidak terlepas dari penjelasan secara lisan oleh pendidik (Hamdayana, 2016, pp. 96-97); (4) Metode Latihan/Drill disebut juga metode training, yaitu metode dengan melatih peserta didik terhadap bahan yang sudah diajarkan atau diberikan agar memiliki ketangkasan atau ketrampilan dari apa yang telah dipelajari (Sudjana, 2014); (5) Metode Diskusi, merupakan salah satu cara mendidik yang berupaya memecahkan masalah yang dihadapi, baik dua orang atau lebih yang masingmasing mengajukan argumentasinya untuk memperkuat pendapatnya (El Khuluqo, 2017, p. 135); (6) Metode Role Playing adalah suatu cara penguasaan bahan-bahan ajar melalui pengembangan imajinasi dan penghayatan siswa (Hamdayana, 2016, p. 102); (7) Metode Imitasi merupakan suatu respon yang serupa dengan stimulus atau rangkaian laku yang ditimbulkan karena mengamati tingkah laku yang serupa pada orang lain; (8) Metode Tutor Sebaya merupakan metode dengan menunjuk peserta didik untuk membantu temannya yang mengalami kesulitan dalam belajar agar temannya tersebut dapat 
memahami materi dengan baik (Ahmadi \& Supriyono, 2004, p. 15). Metode Outdoor Study (pembelajaran di luar kelas) adalah suatu metode dengan upaya mengajak lebih dekat pada sumber belajar yang sesungguhnya yaitu masyarakat dan alam (Adelia, 2012, pp. 14-17).

Seni tari merupakan salah satu warisan kebudayaan Indonesia yang harus dikembangkan dan dilestarikan selaras dengan masyarakat yang selalu mengalami perubahan (Mulyani, 2016, p. 49). Menurut Soedarsono, pengertian tari adalah ekspresi jiwa manusia yang diungkapkan melalui gerak-gerak ritmis yang diperindah (Hidajat, 2018, p. 55). Tari merupakan alat ekspresi ataupun sarana komunikasi seorang seniman kepada orang lain (penonton/penikmat). Sebagai alat ekspresi, tari mampu menciptakan untaian gerak yang dapat membuat penikmatnya peka terhadap suatu yang ada dan terjadi di sekitarnya, sebab tari adalah sebuah ungkapan, pernyataan, dan ekspresi dalam gerak yang bisa memuat komentar-komentar mengenai realitas kehidupan, yang bisa merasuk di benak penikmatnya setelah pertunjukan selesai (Jazuli, 1994).

Mewujudkan sifat alamiah pada tari, perlu kiranya mengetahui unsur pokok tari yaitu elemen gerak tari yang terdiri dari ruang, waktu, dan tenaga. Ruang merupakan unsur pokok dalam tari yang juga akan menentukan hasil atau menentukan terwujudnya suatu gerak tari (Mulyani, 2016, p. 55). Ruang dalam tari berupa posisi, level, dan jangkauan gerak.

Evaluasi hasil pembelajaran seni tari terdapat beberapa aspek yang perlu diperhatikan yaitu wiraga, wirama, dan wirasa. Wiraga, wirama, dan wirasa menjadi suatu sistem pengkategorian yang lazim digunakan sebagai tolak ukur pada tari. Wiraga merupakan ungkapan secara fisik dari awal sampai akhir menari. Wiraga erat hubungannya dengan cara meniru bentuk fisik tari, terutama dari segi geraknya. Keterampilan gerak penari dinilai dengan ketentuan (indeks nilai) yang telah ditetapkan. Misalnya bagaimana bentuk fisik dan geraknya. Wirama akan terungkap jika penari memiliki ketajaman rasa atau kepekaan irama yang luluh menyatu dengan setiap ungkapan geraknya. Kepekaan penari terhadap irama sangat menentukan kualitas tariannya. Wirasa menyangkut penjiwaan atau kemampuan penari di dalam mengungkapkan emosi yang sesuai dengan isi atau tema atau karakter dari suatu tarian (Mulyani, 2016, pp. 52-54). Seorang penari harus memiliki penjiwaan dalam membawakan suatu tarian, agar pesan atau makna dalam tarian dapat tersampaikan. Penerapan wiraga dan wirama tarinya harus selalu mengingat arti atau makna yang terdapat pada suatu tarian sehingga penari dapat tampil dengan penjiwaan secara utuh.

Berdasarkan uraian yang telah dipaparkan diatas, tujuan penelitian ini yaitu untuk mengetahui dan mendeskripsikan metode pembelajaran yang diterapkan pada pembelajaran Tari Rumeksa di Sanggar Dharmo Yuwono Purwokerto.

\section{Metode Penelitian}

Metode penelitian yang digunakan pada penelitian ini yaitu metode deskriptif kualitatif. Penelitian ini menggunakan dua sumber data yaitu data primer dan data sekunder. Sumber data primer berupa ketua sanggar, pengajar, mantan Bupati Banyumas, seniman Banyumas, dan peserta didik pada pembelajaran Tari Rumeksa. Sedangkan data sekunder berupa dokumentasi foto dan video pembelajaran Tari Rumeksa. Teknik pengumpulan data mennggunakan observasi, wawancara, studi pustaka, dan dokumentasi.

Data yang telah terkumpul selanjutnya divalidasi menggunakan teknik triangulasi. Triangulasi yang digunakan yaitu triangulasi sumber dan metode. Selanjutnya data dianalisis dengan reduksi data, penyajian data, pengambilan kesimpulan.

\section{Hasil dan Pembahasan \\ Deskripsi Tari Rumeksa}

Tari Rumeksa adalah tarian yang menggambarkan beberapa kesenian yang ada di daerah Banyumas. Tari ini merupakan hasil kreasi inovasi kesenian tradisional yang tumbuh subur di wilayah Banyumas. Kata rumeksa diambil dari kata ngreksa yang berarti memelihara atau menjaga. Menjaga yang dimaksud ialah untuk menjaga kesenian di Banyumas yaitu Lengger dan Ebeg. Tari Rumeksa terdapat tiga macam kesenian Banyumas yaitu Lengger, Baladewan, dan Ebeg. Tari ini dikategorikan sebagai tari putri yang memiliki ketegasan dan kegagahan pada geraknya, karena pada Tari Rumeksa terdapat Kiprahan dan Ebeg-ebegan yang menggunakan tanjak putra dengan ciri kaki tanjak atau dibuka lebar. Selain itu, kesan centil dan kemayu dapat ditemui pada lenggeran pada bagian awal dan akhir. Tari Rumeksa merupakan tari tunggal yang bisa ditarikan secara kelompok dengan jumlah penari dua orang atau lebih dan dapat ditarikan 
oleh anak-anak, dewasa atau ibu-ibu artinya tidak ada batasan umur untuk menarikan tarian ini. Tari Rumeksa menggunakan properti berupa Ebeg atau kuda kepang yang digunakan untuk ebeg-ebegan. Ebeg lazim ditarikan oleh penari putra sehingga pemakaian properti kuda kepang ini merupakan keunikan dari Tari Rumeksa. Stuktur Koreografi pada Tari Rumeksa terbagi menjadi empat bagian, yaitu lenggeran awal, kiprahan, ebeg-ebegan dan lenggeran akhir. Setiap bagian terdiri dari tiga motif gerak. Motif gerak tersebut merupakan gerakan yang sudah ada kemudian.

Tata rias yang digunakan pada Tari Rumeksa menggunakan tata rias korektif atau rias cantik. Rias korektif dipilih agar keceriaan dan kegembiraan dalam menari Tari Rumeksa terlihat, selain itu rias korektif dapat mempertegas garis-garis wajah dan membuat karakter terlihat cantik, penampilan penari semakin jelas tanpa mengubah karakter asli dari si penari.

Tari Rumeksa merupakan tarian yang terdapat dua watak yaitu kemayu dan gagah. Busana dengan kain nyamping digunakan saat melakukan gerakan lenggeran atau berwatak kemayu. Busana jeblosan digunakan saat melakukan gerakan bagian kiprahan atau berwatak gagah. Busana jeblosan yaitu busana yang berlapis-lapis dari jarik yang dibuat rok dan memiliki wiru, kemudian kain disingkap ke belakang untuk mempermudah saat melakukan gerakan gagahan. Busana yang dikenakan dalam Tari Rumeksa adalah kain batik atau jarik, mekak, slepe, rapek, rompi, celana, dan sampur. Aksesoris yang dipakai meliputi kalung, giwang, gelang tangan, sanggul kerucut, bunga hias, dan hiasan kepala.

Penggunaan iringan musik pada tari berpengaruh dalam menentukan dramatik sebuah tarian. Tari Rumeksa diiringi dengan menggunakan Calung Banyumasan. Calung merupakan alat musik tradisional dengan perangkat mirip gamelan yang terbuat dari bambu wulung. Tari Rumeksa diiringi gending lancaran Banyumasan dengan vokal waranggana. Gending pada Tari Rumeksa menggunakan gending lengger calung, maskot bawor, dan eling-eling. Gending lengger calung digunakan pada bagian lenggeran awal dan lenggeran akhir. Gending maskot bawor pada bagian kiprahan, dan gending eling-eling pada bagian ebeg. Tari Rumeksa menggunakan iringan yang sedang dan cepat sehingga menghasilkan iringan yang rancak dan semangat.

\section{Proses Pembelajaran Tari Rumeksa}

Pemilihan materi Tari Rumeksa pada tingkatan keempat peserta didik dikarenakan mereka dianggap sudah mampu dan sudah melewati tari dasar. Selain itu, Tari Rumeksa merupakan tarian inovasi dari kesenian yang ada di Banyumas yaitu lengger, ebeg, dan baladewan, sehingga materi Tari Rumeksa dapat mengenalkan kesenian tersebut. Pelaksanaan pembelajaran Tari Rumeksa ini memiliki beberapa unsur, antara lain:

\section{Pengajar}

Pengajar Tari Rumeksa di Sanggar Dharmo Yuwono adalah sekaligus juga penata tari dalam penciptaan Tari Rumeksa. Pengajar terkait tidak hanya menjadi penata Tari Rumeksa, tetapi juga sering menjadi penata tari yang lainnya sehingga banyak event atau kegiatan yang sering dilakukan.

\section{Peserta Didik}

Peserta didik pada pembelajaran Tari Rumeksa di Sanggar Dharmo Yuwono berjumlah 25 anak. Peserta didik yang mengikuti pembelajaran Tari Rumeksa rata-rata merupakan siswa yang masih bersekolah di bangku SD dan SMP dengan mayoritas anak perempuan.

\section{Jadwal Pembelajaran}

Jadwal pembelajaran Tari Rumeksa yaitu dua kali setiap pekan. Waktu pembelajaran adalah satu setengah jam (90 menit). Pemilihan hari dan waktu disesuaikan dengan jadwal peserta didik dan pengajar.

\section{Langkah-langkah Pembelajaran}

Kegiatan pembelajaran Tari Rumeksa dilakukan dengan langkah-langkah berikut: (1) Kegiatan pendahuluan, belajar mengajar diawali dengan salam dan doa bersama yang dipimpin oleh salah satu peserta didik. Kemudian dilanjutkan dengan apersepsi yaitu guru menerangkan sekilas tentang materi Tari Rumeksa yang akan dipelajari. Kegiatan ini dilakukan untuk menyiapkan peserta didik secara psikis dan fisik guna mengikuti proses pembelajaran tari, memberi motivasi, dan tanya jawab. Kegiatan ini dilakukan terutama untuk menciptakan suasana awal pembelajaran dan membuat peserta didik lebih fokus dalam mengikuti pembelajaran; (2) Kegiatan inti, pengajar mulai memberi materi gerak dengan menjelaskan terlebih dahulu kemudian memperagakan gerakan Tari. Setelah itu, peserta didik mengikuti gerakan yang diajarkan. Peserta didik diajarkan gerakan dengan hitungan terlebih 
dahulu, setelah hafal kemudian menggunakan iringan musik Tari Rumeksa. Setiap pertemuan diberikan dua sampai tiga ragam gerak kemudian diulang-ulang sampai peserta didik hafal dan paham. Pengajar biasanya membagi kelas menjadi dua agar pembelajaran lebih efektif. Pengajar membenahi gerak pada setiap peserta didik yang kurang bisa dalam memperagakan materi gerak yang diajarkan; (3) Kegiatan penutup, kegiatan penutup adalah untuk menenangkan dan evaluasi pada seluruh aktivitas pembelajaran yang telah dilakukan. Pengajar melakukan penutup untuk memberikan hasil evaluasi, melakukan tindak lanjut dalam pemberian tugas, dan menginformaskan rencana kegiatan untuk pertemuan berikutnya. Kemudian pembelajaran ditutup dengan doa bersama yang dipimpin oleh salah satu peserta didik.

\section{Metode Pembelajaran Pada Tari Rumeksa}

Pengajar menggunakan metode saat pelaksanaan pembelajaran agar tujuan pembelajaran dapat tercapai dengan baik. Metode tersebut dilakukan secara bertahap dan berurutan dengan uraian sebagai berikut:

\section{Metode Ceramah}

Metode ceramah merupakan metode yang dapat dikatakan sebagai metode tradisional karena sejak dulu metode ini telah dipergunakan sebagai alat komunikasi lisan antara guru dan peserta didik dalam interaksi pembelajaran (Hamdayana, 2016, p. 96). Metode ceramah berisi tentang pengetahuan secara terinci sebelum masuk pada pembahasan pokok pembelajaran. Pengajar menerangkan secara lisan tentang materi yang akan diajarkan. Metode ceramah pada pertemuan pertama digunakan pengajar untuk menjelaskan pengetahuan tentang Tari Rumeksa. Pengajar menjelaskan sejarah penciptaan, fungsi, bentuk penyajian, tata rias busana, dan motif gerak pada Tari Rumeksa.

\section{Metode Demonstrasi}

Metode demonstrasi merupakan metode peragaan atau mempertunjukkan sesuatu dengan mempraktikkan materi yang disampaikan. Setelah dilakukan metode ceramah atau penyampaian materi secara teori dan lisan, kemudian pengajar memperagakan gerakan dengan cara mendemonstrasikan setiap gerakan. Dalam pelaksanaan metode demonstrasi ini, pengajar memperagakan setiap motif geraknya tidak dengan hitungan, melainkan mengikuti alunan lagu dan irama kendang tarian tersebut. Hal ini dilakukan karena setiap motif gerak Tari Rumeksa tidak bisa diperagakan dengan hitungan secara pasti. Uraian gerak dan alunan lagu Tari Rumeksa secara lengkap dapat dilihat di Tabel 1.

Tabel 1. Uraian gerak dan alunan lagu Tari Rumeksa

\begin{tabular}{|c|c|c|c|}
\hline $\begin{array}{l}\text { Motif } \\
\text { Gerak }\end{array}$ & Alunan Lagu & $\begin{array}{c}\text { Irama } \\
\text { Kendang }\end{array}$ & Hitung \\
\hline \multirow[t]{4}{*}{$\begin{array}{l}\text { Penthan } \\
\text { gan Asta }\end{array}$} & Seni calung & $\begin{array}{l}\text { Ketak } \\
\text { detungtung } \\
\text { taktak }\end{array}$ & $1-4$ \\
\hline & $\begin{array}{l}\text { Tradisi } \\
\text { banyumasan }\end{array}$ & $\begin{array}{l}\text { Ketak } \\
\text { detungtung } \\
\text { dah dah }\end{array}$ & $5-8$ \\
\hline & Lenggeran & $\begin{array}{l}\text { Ketak de } \\
\text { tungtung tak } \\
\text { tak }\end{array}$ & $1-4$ \\
\hline & $\begin{array}{l}\text { Jogede dadi } \\
\text { klangenan }\end{array}$ & $\begin{array}{l}\text { Ketak } \\
\text { detungtung } \\
\text { dah dah }\end{array}$ & $5-8$ \\
\hline \multirow[t]{5}{*}{$\begin{array}{l}\text { Pentang } \\
\text { an astho } \\
\text { ngracik }\end{array}$} & $\begin{array}{l}\text { Lenggak } \\
\text { lenggo-e }\end{array}$ & $\begin{array}{l}\text { Ketak } \\
\text { detungtung } \\
\text { tak }\end{array}$ & $1-4$ \\
\hline & $\begin{array}{l}\text { Bareng } \\
\text { lembehane }\end{array}$ & Detak tak & $5-8$ \\
\hline & $\begin{array}{l}\text { Tragal tregel } \\
\text { polahe }\end{array}$ & Detak tak & $1-4$ \\
\hline & $\begin{array}{l}\text { Gawe greget } \\
\text { iramane }\end{array}$ & Detak tak & $5-8$ \\
\hline & Senggake & Detak tak & $1-4$ \\
\hline \multirow[t]{4}{*}{$\begin{array}{l}\text { Menuju } \\
\text { keweran }\end{array}$} & $\begin{array}{l}\text { Melu } \\
\text { kendangane }\end{array}$ & $\begin{array}{l}\text { Ndang } \\
\text { ndang ndang } \\
\text { det tak dlang }\end{array}$ & $5-8$ \\
\hline & $\begin{array}{l}\text { Gat e gote } \\
\text { gat e got }\end{array}$ & $\begin{array}{l}\text { Tak tung tak } \\
\text { tlang tung } \\
\text { tak tung tak }\end{array}$ & $1-4$ \\
\hline & $\begin{array}{l}\text { Ndal endhol } \\
\text { endhal ndhol }\end{array}$ & $\begin{array}{l}\text { Ndang detak } \\
\text { ndedlang }\end{array}$ & $5-8$ \\
\hline & E pancen & $\begin{array}{l}\text { Tak detung } \\
\text { tak tung dah }\end{array}$ & $1-4$ \\
\hline \multirow[t]{3}{*}{ Sindhet } & $\begin{array}{l}\text { Nambahi } \\
\text { rasane }\end{array}$ & $\begin{array}{l}\text { Tlang tung } \\
\text { tak delang } \\
\text { tung tak deh }\end{array}$ & $5-8$ \\
\hline & Mleketaket & $\begin{array}{l}\text { Tung deh } \\
\text { tung deh }\end{array}$ & $1-4$ \\
\hline & $\begin{array}{l}\text { Tradisi } \\
\text { banyumasane }\end{array}$ & $\begin{array}{l}\text { Delang } \\
\text { ketung tak } \\
\text { ndedlang }\end{array}$ & $5-8$ \\
\hline
\end{tabular}

Metode demonstrasi ini cocok digunakan pada pembelajaran tari, karena peserta didik dapat lebih memahami gerakan dan lebih mudah untuk memeragakan praktiknya. Pengajar memperagakan setiap gerakan kemudian peserta didik mempraktikkannya agar siswa melakukan praktik gerak yang telah didemonstrasikan, sehingga metode ini perlu digunakan pada pembelajaran Tari Rumeksa karena memerlukan peragaan gerak secara langsung. 


\section{Metode Imitasi}

Metode imitasi merupakan suatu proses peniruan oleh peserta didik dalam melakukan tindakan seperti yang dicontohkan oleh pengajar. Pengajar memberikan contoh materi gerak Tari Rumeksa terlebih dahulu untuk memberikan sedikit gambaran kepada peserta didik, kemudian peserta didik menirukan gerakan dengan perlahan-lahan. Penggunaan metode ini diikuti dengan ngede atau bercermin, pengajar bergerak seolah mereka adalah cermin dari peserta didik, sehingga peserta didik lebih mudah menirukan gerakan yang dicontohkan. Metode ini memudahkan peserta didik secara bertahap dalam menerima materi karena peserta didik dituntun untuk memperhatikan terlebih dahulu sebelum menirukan gerak tarinya.

\section{Metode Latihan / Drill}

Metode latihan merupakan metode pengajaran peserta didik terhadap materi yang telah diajarkan atau diberikan agar peserta didik memiliki ketangkasan atau ketrampilan dari apa yang telah dipelajari (Sudjana, 2014). Setelah peserta didik dapat meniru dan memahami gerakan, pengajar kemudian menggunakan metode latihan. Pembelajaran Tari Rumeksa menggunakan metode latihan agar peserta didik memiliki kemampuan motorik untuk menarikan Tari Rumeksa dengan hafalan serta sikap yang baik dan benar. Metode ini menuntut peserta didik agar melakukan latihan secara langsung dan diulang-ulang dan diatur sedemikian rupa oleh pengajar sehingga peserta didik memperoleh ketangkasan dan perkembangan yang signifikan.

Musik atau iringan tari memiliki peran penting saat berlangsungnya metode latihan ini, karena dapat melatih peserta didik agar mampu menarikan tarian sesuai iringannya. Metode ini digunakan pada Tari Rumeksa agar peserta didik dapat mempraktikkan gerak dari bagian lenggeran awal sampai lenggeran akhir dengan baik dan benar.

\section{Metode Tutor Sebaya}

Merupakan metode pembelajaran dengan beberapa peserta didik ditunjuk atau ditugaskan untuk membantu temannya yang mengalami kesulitan dalam belajar agar temannya tersebut dapat memahami materi dengan baik (Ahmadi \& Supriyono, 2004, p. 15). Metode tutor sebaya merupakan kegiatan belajar mengajar pada sebuah kelas yang memberi kesempatan pada peserta didik untuk mengajarkan dan berbagi ilmu pengetahuan atau ketrampilan pada peserta didik yang lain, metode ini bertujuan juga untuk membantu teman sesama peserta didik yang mengalami kesulitan dalam belajar. Tutor sebaya ini dapat memberi rasa nyaman terhadap peserta didik karena pada umumnya hubungan antara teman lebih dekat dibandingkan hubungan dengan pengajar.

Proses pembelajaran ini termasuk pembelajaran yang bersifat mandiri karena peserta didik menggantikan fungsi pengajar untuk membantu menyampaikan materi. Pembelajaran Tari Rumeksa menggunakan metode ini dengan cara membagi kelas dalam kelompok-kelompok kecil. Setiap kelompok terdapat 1-2 peserta didik yang menurut pengajar sudah dianggap mampu dan dapat memberi contoh kepada temannya yang lain, karena dalam pembelajaran ini peserta didik yang menjadi tutor hendaknya mempunyai kemampuan yang lebih tinggi dibandingkan dengan teman yang lainnya. Pengajar juga tetap mengawasi dan membimbing pada setiap kelompok. Selanjutnya, setiap kelompok diberi kesempatan untuk menari dan mempresentasikan hasil belajarnya.

Metode ini sudah tepat digunakan, karena banyak materi gerak yang belum bisa dipahami tetapi ingin bertanya kepada pengajar tidak berani atau merasa malu, karena tidak semua anak mempunyai keberanian dan rasa percaya diri yang sama. Selain itu, penggunaan metode ini dapat mempererat hubungan antar peserta didik, dan menambah rasa sosial, karena peserta didik bukan dari satu sekolah yang sama melainkan berasal dari sekolah yang berbeda, umur yang berbeda, dan daerah yang berbeda.

\section{Metode Outdoor Study}

Pengajar pada kelas Tari Rumeksa juga menggunakan metode outdoor study atau pembelajaran di luar kelas. Metode outdoor study (pembelajaran di luar kelas) adalah suatu metode dengan upaya mengajak lebih dekat dengan sumber belajar yang sesungguhnya yaitu masyarakat dan alam (Adelia, 2012). Pengajar seringkali melakukan pembelajaran di luar sanggar seperti di taman kota, alun-alun, dan car free day. Hal tersebut dilakukan guna mencari suasana baru untuk peserta didik dan melatih supaya lebih percaya diri, karena taman kota atau alun-alun merupakan tempat yang ramai sehingga akan banyak yang menyaksikan proses pembelajaran tersebut. Selain itu, hal ini dilakukan agar pembelajaran menjadi menyenangkan sehingga tercipta pembelajaran yang terhindar dari kejenuhan, kebosanan, dan persepsi belajar kaku di dalam kelas. 
Penggunaan metode ini diikuti dengan simulasi yaitu peserta didik dan pengajar menggunakan situasi tiruan untuk memahami tentang konsep, prinsip, atau keterampilan tertentu. Peserta didik pada Tari Rumeksa melakukan simulasi seolah mereka sedang melakukan pentas dengan dilihat banyak orang. Hal tersebut dilakukan untuk melihat kemungkinan terjadi kendala seperti kendala teknis dan kendala tidak terduga lainnya saat pementasan berlangsung. Metode simulasi dapat digunakan sebagai metode mengajar dengan merasakan situasi yang sebenarnya dalam artian tahapan yang dilakukan belum ada obyek yang sebenarnya atau tidak pada situasi yang sebenarnya (Sanjaya, 2008, p. 159). Hal tersebut sesuai dengan pembelajaran Tari Rumeksa yang dilakukan di luar sanggar, yaitu guna membiasakan peserta didik agar terbiasa saat menari di luar sanggar dan sudah percaya diri saat mengikuti pementasan akhir tahun yang diadakan di luar sanggar.

Proses pembelajaran menggunakan metode outdoor study ini untuk melatih peserta didik berinteraksi dengan lingkungan sekitar dan dapat meningkatkan kemandirian peserta didik, hal tersebut dikarenakan peserta didik dilatih untuk mengembangkan kreativitas dengan seluasluasnya, meningkatkan kesadaran, dan apresiasi. Maka dari itu penggunaan metode ini dapat dikatakan lebih efektif dibandingkan metode yang lainnya, meskipun pembelajaran dilakukan diluar sanggar yang ramai tetapi metode ini dapat menumbuhkan motivasi tersendiri pada peserta didik untuk tampil lebih percaya diri. Peserta didik cukup berkembang karena proses pembelajaran tidak monoton dilakukan didalam kelas saja melainkan diselingi dengan belajar diluar sanggar agar imajinasi peserta didik lebih aktif tidak hanya terpaku pada keadaan di dalam kelas.

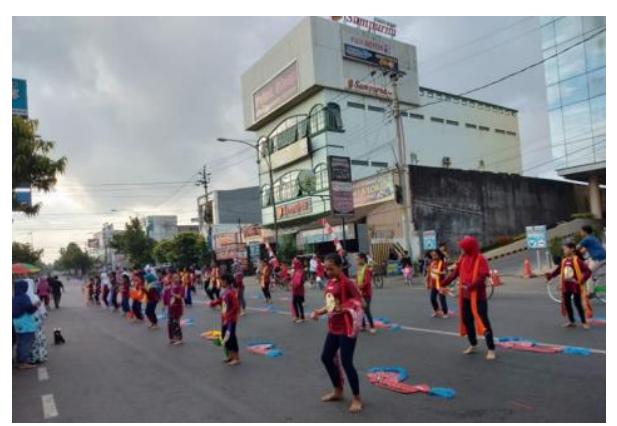

Gambar 1. Proses Pembelajaran Outdoor Study Tari Rumeksa
Sanggar Dharmo Yuwono Purwokerto telah menggunakan metode yang cocok dalam pembelajaran Tari Rumeksa. Metode tersebut dilakukan secara bertahap dan berurutan sehingga dapat tercapai tujuan pembelajaran yang diinginkan, yaitu peserta didik dapat menguasai dan menarikan Tari Rumeksa dengan baik dan benar. Metode outdoor study juga dianggap cara yang efektif untuk melakukan pembelajaran tari. Hal tersebut dikarenakan pembelajaran tari melalui lingkungan di luar sanggar yang ramai dapat menumbuhkan motivasi tersendiri terhadap peserta didik agar dapat tampil lebih percaya diri.

\section{Kesimpulan}

Berdasarkan hasil yang telah ditemukan, disimpulkan bahwa aspek pembelajaran tari yang dilaksanakan di Sanggar Dharmo Yuwono sudah berjalan dengan baik, terutama dari penggunaan metode pembelajaran sehingga peserta didik dapat mengikuti proses dengan baik, mudah menangkap materi yang diajarkan, serta dapat mencapai tujuan pembelajaran. Metode pembelajaran yang digunakan merupakan metode yang umum digunakan dalam pembelajaran yaitu metode ceramah, metode demonstrasi, metode imitasi, metode latihan atau drill, metode tutor sebaya dan metode outdoor study.

Pengajar menggunakan metode tersebut disesuaikan dengan kemampuan peserta didik sehingga peserta didik dapat lebih mudah menangkap materi yang diajarkan. Pengajar menerapkan metode ceramah sebagai pendahuluan atau pembukaan untuk menjelaskan materi yang disampaikan. Metode demonstrasi digunakan untuk memperagakan materi yang diajarkan, selanjutnya peserta didik mempraktikkan dengan menirukan yang telah diperagakan oleh pengajar. Penggunaan metode imitasi agar peserta didik lebih mudah dalam menirukan, pengajar juga menggunakan cara bercermin atau ngede. Selanjutnya metode latihan digunakan untuk melatih ketrampilan tiap peserta didik. Metode tutor sebaya dilakukan dengan cara salah satu peserta didik menjadi tutor kemudian menjelaskan kepada temannya. Metode outdoor study dilakukan agar tercipta suasana pembelajaran yang baru yang membuat peserta didik tidak merasa bosan dan jenuh, selain itu juga untuk menambah rasa percaya diri pada peserta didik. 


\section{Referensi}

Adelia, V. (2012). Metode Mengajar Anak Di Luar Kelas (Outdoor Study). Yogyakarta: Diva Press.

Ahmadi, A., \& Supriyono, W. (2004). Psikologi Belajar. Jakarta: Rineka Cipta.

El Khuluqo, I. (2017). Belajar dan Pembelajaran: Konsep Dasar, Metode dan Aplikasi Nilai-Nilai Spiritualitas dalam Proses Pembelajaran. Yogyakarta: Pustaka Pelajar.

Ginting, A. (2008). Esensi Praktis Belajar dan Pembelajaran. Bandung: Humaniora.

Hamdayana, J. (2016). Metodologi Pengajaran. Jakarta: Bumi Aksara.

Hidajat, R. (2018). Tari Pendidikan. Yogyakarta: Media Kreativa.

Jazuli, M. (1994). Telaah Teoritis Seni Tari. Semarang: IKIP Semarang Press.

Kaniah, K. (2017). 9 Metode Pembelajaran Efektif Dan Menyenangkan: Best Practice Pembelajaran PAI Inovatif. Yogyakarta: Pustaka Pelajar.

Mudjiman, H. (2007). Belajar Mandiri. Surakarta: UNS Press.

Mulyani, N. (2016). Pendidikan Seni Tari Anak Usia Dini. Yogyakarta: Gava Media.

Sanjaya, W. (2008). Strategi Pembelajaran Berorintasi Standar Proses Pendidikan. Jakarta: Kencana Prenada Media.

Sudjana, N. (2014). Dasar-Dasar Proses Belajar Mengajar. Bandung: Sinar Baru Algensindo. 